\title{
Socio-cultural Obstacles in the Way of Women Participation in Politics: A Case Study of District Charsadda, Pakistan
}

\author{
Shehla Khan*1 and Musawar Shah ${ }^{2}$ \\ 1. Department Sociology, University of Peshawar, Peshawar, Pakistan. \\ 2. Department Rural Sociology, Agriculture University, Peshawar, Pakistan. \\ * Corresponding Author Email: shehlakhan@ uop.edu.pk
}

\begin{abstract}
Political participation is one of the important factors of empowerment and creates awareness among females about their rights in a society. Equal distribution of power, authority, rights, needs and participation etc. are the need of an hour. In male dominant society women are not allow to participate in politics, caste vote and contest in the politics as a member. In Pakhtun society specifically in district Swat females are confronted much more miseries and dilemmas to take part in active politics. The primary facts were collected through simple random sampling technique where the total population, was 196 in the target area of the study. After the collection of the primary data then the researcher analyzed the empirical data through SPSS (Statistical Package for Social Sciences). The data were analyzed in two phases in the first phase of the analysis the frequency and percentages have come out through descriptive statistics in univariate and the bivariate data were analyzed by applying Chi-square test to see the association level between independent variable (social and cultural values) and dependent variables (women participation in active politics) in inferential statistics. Through the political participation of women, it can easily encourage and award women to address their issues and solve them according to their own wishes and desire. The study recommended that although women had liberty, however religious misinterpretation were in prevalence. Also this is recommended that women participation in social and cultural values improve the women part in active politics.
\end{abstract}

Keywords: Women Empowerment, Social Values, Cultural Values, Women in Politics.

\section{How to Cite:}

Khan, S. \& Shah, M. (2020). Socio-cultural Obstacles in the Way of Women Participation in Active Politics: A Case Study of District Charsadda, Pakistan. Journal of Humanities, Social and Management Sciences (JHSMS), 1(1), 53-65. https://doi.org/10.47264/idea.jhsms/1.1.5

\section{Publisher's Note:}

IDEA PUBLISHERS (IDEA Journals Group) stands neutral regarding jurisdictional claims in the published maps and institutional affiliations.

\section{Copyright:}

(C) 2020 The Author(s), published by IDEA PUBLISHERS (IDEA Journals Group)

This is an Open Access article published under the Creative Commons Attribution-NonCommercial 4.0 International License (http://creativecommons.org/licenses/by-nc/4.0/) 
Socio-cultural Obstacles in the Way of Women Participation in Politics: A Case Study of ...

\section{Introduction}

In Pakistani context female have a very undermine status with great disappointment as having not merely narrow admittance to rudimentary facilities of survival but are also expose to numeral liabilities which male play a responsibility as a substitute of factual employed force to add in the development process (Brand,1998 \& Naz,2011). The study of Coleman, (2004) have reported that women as the utmost ignored sector of our society with controlled movement for the purpose of occupation or work and contribution in overall tasks of the development. Whereas, cultural discrepancy is intensely working on transferring the practice of socialization which determines the men in leading status. Thus, the over-all world indicates the significance gender and especially women associated with in respect of its employment and progression in the arena of social life. In Indian culture gender development is similarly delimited to male supremacy with patriarchal reflection (Sadie, 1995; Hirway \& Mahadevia, 1996).

Mostly women empowerment in Asian cultures are misconstrued and limit their performance to household events. But it mean that the capacity and aptitude to choose work. On the other hand, the level of approach to material and social means enable them truly empowerment in various segments (Coleman, 2004). Due to patriarchy system, Pakistani social structure creates a strong division of labor on gender basis in different activities. Women are generally connected in performing restricted activities while a male has all the liberty to enjoy it. This inconsistency was found in all domain of human life such as lack of educational empowerment and political contribution where men are relishing socio-cultural hegemony over female in diverse domains (Tisdell, 2002). It may possibly assume and aware about through the data revealed in subsequent table.

Table-1: Gender gap in education, labour force participation, and political Participation

\begin{tabular}{|c|c|c|c|c|}
\hline & Male & Female & Gap & Rand in World \\
\hline Literacy rate Pakistan & 67.0 & 42.0 & 25.0 & \multirow{2}{*}{$\begin{array}{l}122 \text { out of } 134 \text { courtiers Global Gender } \\
\text { Gap Index }\end{array}$} \\
\hline $\begin{array}{l}\text { Population ever attended school } \\
\text { Pakistan }\end{array}$ & 69.0 & 44.0 & 25.0 & \\
\hline $\begin{array}{l}\text { Labour force participation } \\
\text { Pakistan }\end{array}$ & 70.1 & 19.1 & 51.0 & $\begin{array}{l}127 \text { out of } 128 \text { countries Gender } \\
\text { Competitiveness Index }\end{array}$ \\
\hline $\begin{array}{l}\text { Political participation National } \\
\text { Assembly Senate }\end{array}$ & $\begin{array}{l}79.0 \\
82.0\end{array}$ & $\begin{array}{l}21.0 \\
18.0\end{array}$ & $\begin{array}{l}58.0 \\
64.0\end{array}$ & $\begin{array}{l}50 \text { out of } 134 \text { counties Global Gender } \\
\text { Gap Index }\end{array}$ \\
\hline
\end{tabular}

Source: GOP (2008), GOP (2007), GOP (2007a), GOP (2006), Hausmann et al. (2008) and World Economic Forum

Women participation in politics as compared to men is very much restricted; however, a sense of relief could be gettable while concentrating on the trend of participation from women in this vital field of human life while comparing with other developing countries. However, a fallacy over women status and low performance is still in prevalence. The government has been introducing a number of policies directions through legislation for bringing the women at par domain. In addition women are still lagging behind in reference to their level of participation. Women in political arena at the grass root have proved some success. The recent devolution paradigm also focuses the women participation in the local bodies for the purpose of mainstreaming the social fabrics at the grass root level to ensure women to fully participate. This study is an approach to highlight the prospective role being performed in part of women while participating in the political process. Furthermore, it would also tried to explore the true 
possibility that whether women could be a proper substitute to men in politics while devising some policy recommendation (Aziz, 2020).

Kanter (1977) perceived it is the situational variables that have retained women from arising to top leadership in modern organizations, the situational variables that have worked against them in the past will work for them if organizations carry on their evolution into places where their style of leadership will fit nicely into the predominant ethos. Thus it seems that professionals' opinions of gender differences in leadership style have taken some interested turns over the past several decades. Initially, there was the impression that men and women had diverse leadership styles based on inborn sex related features. Then the opinion became that, even though there were dissimilarities, women could learn to be successful in organizations by being more like men. All along, there were social researchers who were stressing that there were few variances in male and female styles, and that once women turn into leaders they would act in the similar way as men. Now the pendulum has swung once more, and there is again an observation that there are dissimilarities in the leadership styles of men and women. This time, however, declarations are made that these differences will work to the benefit of women because the potentials connected with their administration style is what is desirable today to make organizations more operational.

Loden (1985) distinguished that in some aspects, it seems that women administrators may be well arranged to manage with the encounters of the future than several old-style male leaders who be successful in the past. For several of the features being touted as critical for future success-concern for people, interactive skills, instinctive management and resourceful problem solving-are abilities that women as a group are encouraged to advance and depend on during their lives. The study of Cleveland (1985) found that it is not an opportunity or luck that women are contravention keen on the decision-making marketplace now while the answer to achievement in decision-making labor is operational- with each other public skill."

The socialization and culture effect the perception of leadership of women are prerequisite. Eagly and Carli(2002) discovered the psychological relation of influential base on sexual characteristics, mentioning that sexual characteristics bias supports with societal structure of male and female based on artistic insights and inspirations. The women frequently linked with common potentials of sympathy, love and love, and gentleness, and men associated with instrumental character of declaration, self-assurance, and preeminence. Biased might effect as mismatches or position strangeness among the qualities of stereotyped of women cross the management characters they fill up. Such a way superiority of male over female sex is emerged in a society. Female can be blamed of too much softy. In the light of research based on leadership a female who lead through behaviours conventionally seeming as feminine may find herself at a difficulty (Eagly et al., 1992).

Female who are womanly can be supposed as a smaller amount of competent, causing a "double bind" of mutual exclusivity between the two, creating a delicate balancing act.For example, Hillary Clinton, who is frequently lay off as being too masculine in her leadership behavior, has also been complained for showing emotion, such as during the 2008 New Hampshire primary when she teared up during a question and answer session (Clinton, 2008). Cultural prospects also add to the notion that women should be well-mannered in every condition (Valian, 1998). Moreover, when clashes established between the jobs of leadership and tasks of gender, causing usually prejudice, that can be observed for why it is additionally hard for 
female to be a political elitist and accomplish achievement than for the colleagues of their male (Eagly \& Carli, 2002).

\section{Literature Review}

Leadership is a very castoff word and can have numerous aspects with respect of period and space. This term has been hypothesized by diverse theorists, intellectuals and academicians consequently. These theories describe dissimilar aspects of leadership from various viewpoints; such as psychological, socio-cultural, political, and biological. The Leadership has itself is a very broad nature idea and many concepts and classes of leadership be present. The women leadership is simply one outlet of the notion and can also be described in different methods (Aziz, 2020). Because some recognize women leadership is a fact that female able to be a leader, while others researcher explain it from activist perspective and as a matter of egalitarianism and the right to have the similar opportunities. Several studies stated that it refers to specific feminine features that are valued in today's organizational structure. Whereas others think about that leadership would not be discriminated on the bases of female leadership at all. It is culturally required and variations occur over time, so it is tough to give one meaning of it which spread over to all leadership. On the other hand, to realize the meaning of female leadership and its vital scope will be enlightened further (Palmu-Joronen, 2009).

Social standards work as both a limitation on a lady's versatility and a hindrance to her interest in the general population circle. These social standards are propagated and continued by the ground-breaking foundations of family, position, and religion and affect sexual orientation related issues. It has been noted by the Center for Asia-Pacific Women in Politics that the strengthening of ladies regarding access to basic leadership positions is significantly influenced by social generalizations that exist in many social orders. In the Asia-Pacific locale, the real types of social generalizations incorporate (1) that ladies' essential duty is to deal with the family and kids, and it is just an optional commitment to get engaged with social and political foundations, that ladies need understanding, and in this manner are not fit for accepting administration positions, that the general population space is primarily for men, while the private family area is for ladies, and that ladies' contribution in people in general circle ought to be an expansion of their jobs in the family circle. Such sexual orientation generalizations are established in social standards and Bangladesh isn't a special case in such manner. There is a truism in Bangladeshi culture that "A lady's heaven is at the feet of her significant other." Women who trust this are normally less inclined to oppose conjugal brutality or get associated with exercises outside the home (Haque, 2003).

The conventional male centric culture of Bangladesh depends on class and sexual orientation divisions. Class portability permits development among rich and poor, however the division of social space and the distinction in conduct standards among people are inflexibly kept up. The family, which comprises the fundamental unit of social association and control, sets the standards for male and female jobs. Inside this framework, the dad, or in his nonappearance, the following male kinfolk, is the leader of the house hold. Therefore, both basic leadership powers and monetary control are vested in the hands of men. Moreover, the family works through an obviously characterized arrangement of rights and commitments. This is exhibited when Muslim ladies defer the privilege to acquire their dads' property for siblings or, in case of acquiring property, pass control to their spouses or children. In the two cases, the man offers security to the lady as an end-result of command over her property, in this manner specifically 
fortifying a man centric custom. A spouse frequently compromises his better half with separation on the off chance that she declines to deal with her little girl and make sure that she weds the husband he has chosen for her. In the outrageous patriarchic culture, it is the obligation of a mother to persuade her little girl in the event that she differs to accomplish something the dad requests and ladies don't have the privilege to choose whom to wed (Norris, 2013).

The male centric culture offers little space for ladies to build up their position and office. Subsequently, ladies assume a generally representative job in the basic leadership process. Goetz et al. (2004) offers the contention that the decentralization procedure will in general revive and reinforce existing customary organizations and neighbourhood elites. In addition, society isn't yet prepared to acknowledge ladies commanding the procedure of basic leadership or assuming a positive job. We quote here a discourse by a previous Member of Parliament, Tasnima Hossain, who in her location at a round-table gathering in Dhaka on the "Job of Civil Society and New Media to Prevent Violence against Women," told the group of onlookers: I was not regarded as an associate by different Members in the Parliament. Or maybe I was generally regarded as "bhavi" or the spouse of Anwar Hossain Munjual though I was a chosen MR While I was entering ... the Parliament I needed to hear ["] why [was] I ... alone? Why [had] I... not accompany my Husband? ["] The circumstance resembled that I would need to accompany my significant other to the Parliament without fail (Alo, 2006).

The above model mirrors a circumstance in which ladies experience the ill effects of a character emergency. In a very stratified and sexual orientation one-sided society, ladies individuals are not seen independently from their way of life as "ladies." For example, ladies agents at the nearby dimension don't have particular duties, their sentiments are not heard amid basic leadership, and male partners act adversely toward them (Shamim and Nasreen, 2002). The sufferings of ladies individuals are not limited to issues of character as it were. Now and then they are dealt with seriously on the off chance that they talk up for their rights. At the neighbourhood government level, ladies' underestimation is fortified by the paternalistic and biased states of mind of male agents and male administrators, and their conviction that ladies ought not get engaged with nearby legislative issues and that while men get into office (Mukhopadhyay, 2016).

\section{Material and Methods}

The study was limited to the $75 \%$ union councils of all the three Tehsils of District Swat. The respondents comprised of those women who had contested in local government elections in the targeted district. The primary facts were collected through simple random sampling technique where the total population, was 196 in the target area of the study. From the total population a sample size of 130 councillors were taken through Sekaran (2010) sample size table. The secondary data shows that 196 women had contested in the local body elections in the study area. The total sample size was distributed into various Union Councils on the proportionate basis. To obtained the prime data interview schedule (see annexure-1) was developed in light of the objectives and different variables discussed in the literature review. To check the relevancy and reliability the tools for data collection was pre-tested for refining and accuracy. The interview schedule was used because all of the respondents were not educated and were not knowable about the depth of the questions to solve by their self. After the collection of the primary data then the researcher analyzed the empirical data through SPSS (Statistical Package for Social Sciences). The data were analyzed in two phases in the first phase of the analysis the frequency 
and percentages have come out through descriptive statistics in univariate and the bivariate data were analyzed by applying Chi-square test to see the association level between independent (educational, socio-cultural, gender stereotyping, religion and familial) and dependent variables (women participation in active politics) in inferential statistics. The primary facts were analyzed through using proper statistical techniques i.e. univariate and bivariate level respectively. The bivariate level, Chi square $\chi 2$ test would be used to determined the relationship between dependent variable (women participation in active politics) and independent variables ((educational roles ). To determined the association level the following process was adopted to calculate chi-square as was outlined by Mc call and Robert (1975).

\section{Analysis and Discussion}

\subsection{Univariate Analysis}

This is related to hindrances of social and cultural values of Pashtun social structure in participating of women in politics. In the first statement of the variables majority of the respondents i.e. 80.0 percent said that men recognize women as their equal counterpart in public sphere whereas 11.5 percent respondents did not agree with the statement and the rest of the respondents i.e. 8.5 percent did not share their ideas. In another statement, 86.9 percent of respondents told that most of the women felt the reluctance to accept political responsibilities. The second largest sampled population i.e. 6.9 percent told that they did not feel any type of reluctance in political responsibilities and the remaining 6.2 percent respondents replied as neutral. Furthermore, the majority of the respondents i.e. 83.8 percent replied that being a woman it is quite difficult for women to participate in every training programs of the councillors. Some of the respondents i.e. 9.2 percent said that being a woman it is not so difficult to participate in councillors training programs whereas the remaining 6.9 percent respondents did not share their ideas. Likewise, the majority of the respondents i.e. 79.2 percent told that women face a lot of problems to decision making in politics whereas 11.5 percent respondents did not share their ideas and the remaining 9.2 percent respondents were of the opinion that they have easy access to decision making in politics. Additionally, most of the respondents i.e. 82.3 percent were of the view that developmental funds are equally distributed for male and female problems at council level while the second largest group of respondents i.e. 13.8 percent told that the fund for developmental purpose did not distribute equally for male and female. In the end of the statement some of the respondents i.e. 3.8 percent said that they did not know that the fund distributed equally. In another statement the majority of the respondents i.e., 79.2 percent said that women cannot supervise developmental projects efficiently in their area because every time they did not come out from their homes in Pakhtun society. Some of the respondents i.e. 16.2 percent told that they supervise the developmental projects in a very well manner while the rest of the sampled population i.e. 4.5 percent did not share their experiences regarding the statement. Likewise, the majority of the respondents i.e. 80.8 percent said that Pakhtun did not allow women to cast vote and participate in politics whereas 14.6 percent told that Pakhtun allows women to cast vote and participate in politics. Few of the respondents i.e. 4.6 percent did not share their ideas that they don't know about the statement asked. Furthermore, most of the respondents i.e. 87.7 percent shared their views that patriarchy is the main cause of women low participation in politics, while some of the respondents i.e. 6.9 percent did not agree and 5.4 percent were not aware of the statement. Moreover, 73.1 percent 
respondents said that they did not consider female as low/secondary strata of the society in Pakhtun social structure whereas 24.6 percent agreed and 2.3 percent did not share their views about the statement. In another statement of the variable majority of the respondents i.e. 86.2 percent said that unmarried women performance is best in politics as compared to married women, some of the respondents i.e. 9.2 percent did not know about the statement and in the end 4.6 percent did not agreed with the statement. Furthermore, the statement was about that politics in our country is class based in response majority of the respondents i.e. 82.3 percent agreed with the statement while 10.0 percent did not shared their views and 7.7 percent respondents told that politics in our country is not on class-based.

Table-2: Social and Cultural Values

\begin{tabular}{|l|c|c|c|c|c|c|c|}
\hline Statements & \multicolumn{2}{|c|}{ Yes(\%) } & \multicolumn{2}{|c|}{ No(\%) } & \multicolumn{2}{|c|}{ Neutral(\%) } & Total \\
\hline $\begin{array}{l}\text { Men recognize women as their equal counterparts } \\
\text { in the public sphere }\end{array}$ & 104 & 80.0 & 15 & 11.5 & 11 & 8.5 & 130 \\
\hline $\begin{array}{l}\text { Women are reluctant to accept political } \\
\text { responsibilities }\end{array}$ & 113 & 86.9 & 09 & 6.9 & 08 & 6.2 & 130 \\
\hline $\begin{array}{l}\text { Being a woman is it difficult to participate in the } \\
\text { training programs of the councillors }\end{array}$ & 109 & 83.8 & 12 & 9.2 & 09 & 6.9 & 130 \\
\hline $\begin{array}{l}\text { Women have easily access to decision making in } \\
\text { politics }\end{array}$ & 12 & 9.2 & 103 & 79.2 & 15 & 11.5 & 130 \\
\hline $\begin{array}{l}\text { Developmental funds are equally distributed for } \\
\text { male and female problems/issues at council and } \\
\text { district level }\end{array}$ & 107 & 82.3 & 18 & 13.8 & 05 & 3.8 & 130 \\
\hline $\begin{array}{l}\text { Women can supervise developmental projects } \\
\text { efficiently in their area }\end{array}$ & 21 & 16.2 & 103 & 79.2 & 06 & 4.6 & 130 \\
\hline $\begin{array}{l}\text { Pakhtoon allow women to cast vote and participate } \\
\text { in politics }\end{array}$ & 19 & 14.6 & 105 & 80.8 & 06 & 4.6 & 130 \\
\hline $\begin{array}{l}\text { Patriarchy/male dominancy is the main cause of } \\
\text { women low participation in politics }\end{array}$ & 114 & 87.7 & 09 & 6.9 & 07 & 5.4 & 130 \\
\hline $\begin{array}{l}\text { Females are considered as low/secondary strata } \\
\text { among Pakhtuns }\end{array}$ & 32 & 24.6 & 95 & 73.1 & 03 & 2.3 & 130 \\
\hline $\begin{array}{l}\text { Unmarried women performance is best in politics as } \\
\text { compared to married women }\end{array}$ & 112 & 86.2 & 06 & 4.6 & 12 & 9.2 & 130 \\
\hline Politics in our country is class-based & 110 & 82.3 & 10 & 7.7 & 13 & 10.0 & 130 \\
\hline
\end{tabular}

\subsection{Bivariate Analysis}

The table showed something about the association between social and cultural values of Pakhtun social structure and women participation in politics. A significant association $(p=0.029)$ was found between men recognize women as their equal counterparts in the public sphere and women participation in politics. The result of the study shows that men consider women as their complements, as the study result supported by Kanter (1977). According to Kanter men and women have different leadership patterns on the basis of their biological differences such as their confidence, energy, and power etc. of men as compared to women as they have lack/less these physical and biological capabilities. On the sociological side, there are differences between these two-gender group on masculinity and femininity. As in advance countries, these differences are now very low or rare but in underdeveloped countries like Pakistan specifically in Pakhtun social structure this difference is very much as compared to 
other parts of the country. In Pakhtun society, the patriarchal system not consider and allow women as their counterparts in politics and other spheres of life and activities.

Furthermore, a significant association $(\mathrm{p}=0.001)$ was disclosed between women are reluctant to accept political responsibilities and women participation in politics. The results are shown that $86.9 \%$ counsellors are agree, $6.9 \%$ counsellors are disagree and the rest of $6.2 \%$ are neutral. Additionally, a significant association $(\mathrm{p}=0.004)$ was found between being a woman is it difficult to participate in the training sessions of the councillors, and women participation in politics. In another statement i.e. women have easy access to decision making in politics have a significant association $(\mathrm{p}=0.029)$ with women participation in politics. The findings were related to the research findings of Morna (2002) and Hussain and Siddiqui (2002) according to their results women face reluctance in political activities in rigid societies like in Pakhtun society. Their results show that most of the male politician did not want to provide full opportunity for women in politics because women have the qualities to overcome the problems of the society in a proper way. In some societies, it is very difficult for women to participate in every party or political meeting because in such societies family and other members of the society create problems for women. In a patriarchal society, they are unable to indulge fully in the campaign and other political activities through this way they are unable to give or share their ideas in decision making. In patriarchal society specifically in Pakhtun society, they did not allow their female to participate and empower females in decision making.

Moreover, a non-significant association $(\mathrm{p}=0.178)$ was revealed between developmental funds are equally distributed for male and female issues at council and district level with women participation in politics. The study result supported by Eagly and Carli (2002); Goetz et al. (2004) in their research findings they found that on the basis of higher position in politics the upper authority then distributed the developmental funds on nepotism and favouritism basis. They did not share the developmental funds on the equal basis they neglect the women politician in giving equal funds to both genders. On the basis favouritism and supporting the male politician then the dignity and value of the female politician degrade and they were not able to do some positive measure for their community. Similarly a significant association $(\mathrm{p}=0.026)$ was observed between women can supervise developmental projects efficiently in their areas with women participation in politics. The outcome of the statement braced by the findings of Marilyn Loden (1985) according to his study, women have the qualities to solve the problems in a proper way because without female cooperation no society can get development. Political women know how to deal with the mass and how to know and solve the existing problems in their political jurisdiction. They have the quality to supervise the developmental projects in a proper way, in some areas they face problems by opposing the male politicians but they have the qualities to overcome the issues and develop their area. Furthermore a highly significant association $(\mathrm{p}=0.000)$ was found between women participation in politics and Pakhtun allow women to cast vote and participate in politics. Likewise, a highly significant association $(\mathrm{p}=0.000)$ was observed between male dominance is the main cause of women low participation in politics with the dependent variable i.e. women participation in politics. A non-significant association $(\mathrm{p}=0.733)$ was found between females are considered as low strata among Pakhtun society with women participation in politics. The results of the statements were supported by Eagly and Carli (2002) and Valian (1998) in Patriarchal societies the male members did not allow women to participate and cast vote. High prestigious people in patriarchal societies decide that who cast vote and who will not cast vote. Now in this modern era, the trend is changing in some patriarchal societies women also cast 
vote but their percentage is very low as compared to men. Due to male dominance, the incongruity becomes an increase in the society and the functions of the different institutions disturb. According to Rizvi (1980), women are considered as low part in patriarchal society, like when a male child born everyone become happy while a female child born then everyone becomes sorrow as they consider female as low strata of the society.

Furthermore, a highly significant association $(\mathrm{p}=0.000)$ was found between unmarried women performance is best in politics as compared to a married woman with women participation in politics. The finding of the statement buoyed by Marilyn Loden (1985) in his study that unmarried women have more time to spend in the community and focus on the problems face by the people of the community. Unmarried women have more time as compared to married women because married women have to take care of their children and have also focused on the entire family. According to him in political activities unmarried will contribute more and will solve the problems of the society in a good manner.

A significant association ( $\mathrm{p}=0.005)$ was found between politics in our country is class based on women participation in politics. The study finding reveals that politics in Pakistan and especially in Pakhtun society is class-based, normally the upper-class people participate in politics as compared to lower class people. The study findings of Kanter (1977) were in line with the result of the statement. In his study, he found that in developing and patriarchal countries and societies normally politics is class-based e.g. in Pakistan there are some political leaders who cached the politics of Pakistan like Zulfiqar Ali Bhutto after his death then his daughter Benazir Bhutto Shaheed then her husband Asif Ali Zardari and now his son Bilawal Bhutto. Another example is Nawaz Sharif, Begum Kalsoom Nawaz, Shahbaz Sharif, Maryam Nawaz. It showed that in Pakistan politics are circling around a few families and only highclass people who have a lot of money in their hands have captured the politics of Pakistan. Furthermore, there was a significant association $(\mathrm{p}=0.001)$ disclosed between women are reluctant to accept political responsibilities with women participation in politics. Additionally, in a statement being a woman is it difficult to participate in the training sessions of the councillors, which disclosed a significant association $(p=0.004)$ with women participation in politics. In another statement i.e. women have easy access to decision making in politics have a significant association $(\mathrm{p}=0.029)$ with women participation in politics. The findings were related to the research findings of Morna (2002) and Hussain and Siddiqui (2002) according to their results women face reluctance in political activities in rigid societies like in Pakhtun society. Their results show that most of the male politician did not want to provide full opportunity for women in politics because women have the qualities to overcome the problems of the society in a proper way. In some societies, it is very difficult for women to participate in every party or political meeting because in such societies family and other members of the society create problems for women. In a patriarchal society, they are unable to indulge fully in the campaign and other political activities through this way they are unable to give or share their ideas in decision making. In patriarchal society specifically in Pakhtun society, they did not allow their female to participate and empower females in decision making.

Moreover, a non-significant association $(\mathrm{p}=0.178)$ was revealed between developmental funds are equally distributed for male and female issues at council and district level with women participation in politics. These findings were in line with the study of Eagly and Carli (2002); Goetz et al. (2004) in their research findings they found that on the basis of higher position in 
politics the upper authority then distributed the developmental funds on nepotism and favouritism basis. They did not share the developmental funds on an equal basis they neglect the women politician in giving equal funds to both genders. On the basis favouritism and supporting the male politician then the dignity and value of the female politician degrade and they were not able to do some positive measure for their community. Furthermore a significant association $(\mathrm{p}=0.026)$ was found between women can supervise developmental projects efficiently in their areas with women participation in politics. The outcome of the statement braced by the findings of Marilyn Loden (1985) according to his study, women have the qualities to solve the problems in a proper way because without female cooperation no society can get development. Political women know how to deal with the mass and how to know and solve the existing problems in their political jurisdiction. They have the quality to supervise the developmental projects in a proper way, in some areas they face problems by opposing the male politicians but they have the qualities to overcome the issues and develop their area. It was further explained by the study of findings that a highly significant association $(\mathrm{p}=0.000)$ was found between women participation in politics and Pakhtun allows women to cast vote and participate in politics where. Likewise, a highly significant association $(\mathrm{p}=0.000)$ was observed between male dominance is the main cause of women low participation in politics with women participation in politics. A non-significant association $(\mathrm{p}=0.733)$ was found between females are considered as low strata among Pakhtun society with women participation in politics. These findings had supported from results of the Eagly and (2002) and Valian (1998) in Patriarchal societies the male members did not allow women to participate and cast vote. High prestigious people in patriarchal societies decide that who cast vote and who will not cast vote. Now in this modern era, the trend is changing in some patriarchal societies women also cast vote but their percentage is very low as compared to men. Due to male dominance, the incongruity becomes an increase in the society and the functions of the different institutions disturb. According to Rizvi (1980), women are considered as low part in patriarchal society, like when a male child born everyone become happy while a female child born then everyone becomes sorrow as they consider female as low strata of the society. Furthermore, a highly significant association $(\mathrm{p}=0.000)$ was observed between unmarried women performance is best in politics as compared to a married woman with women participation in politics. These findings were in line to the study by Marilyn Loden (1985) in his study that unmarried women have more time to spend in the community and focus on the problems face by the people of the community. Unmarried women have more time as compared to married women because married women have to take care of their children and have also focused on the entire family. According to him in political activities unmarried will contribute more and will solve the problems of the society in a good manner. In addition a significant association $(\mathrm{p}=0.005)$ was found between politics in our country is class based on women participation in politics. The study finding revealed that politics in Pakistan and especially in Pakhtun society is class-based, normally the upper-class people participate in politics as compared to lower class people. The study findings of Kanter (1977) were in line with the result of the statement. In his study, he found that in developing and patriarchal countries and societies normally politics is class-based e.g. in Pakistan there are some political leaders who cached the politics of Pakistan like Zulfiqar Ali Bhutto after his death then his daughter Benazir Bhutto Shaheed then her husband Asif Ali Zardari and now his son Bilawal Bhutto. Another example is Nawaz Sharif, Begum Kalsoom Nawaz, Shahbaz Sharif, Maryam Nawaz. It showed that in Pakistan politics are circling around a few families and only high-class people who have a lot of money in their hands have captured the politics of Pakistan. 
Table-2: Association between Social and Cultural Values of Pakhtun Social Structure with Participation of Women in Politics

\begin{tabular}{|c|c|c|c|c|c|c|}
\hline \multirow{2}{*}{ Statement } & & \multicolumn{3}{|c|}{$\begin{array}{c}\text { Women Participation in } \\
\text { Politics }\end{array}$} & \multirow{2}{*}{ Total (\%) } & \multirow{2}{*}{ Statistics } \\
\hline & & Yes $(\%)$ & No $(\%)$ & $\begin{array}{l}\text { Neutral } \\
(\%)\end{array}$ & & \\
\hline \multirow{4}{*}{$\begin{array}{l}\text { Men recognize women as their equal } \\
\text { counterparts in the public sphere }\end{array}$} & Yes & $50(38.5)$ & $50(38.5)$ & $04(3.1)$ & $104(80.0)$ & \multirow{4}{*}{$\begin{array}{l}(\mathrm{p}=0.029) \\
(\chi 2=10.782)\end{array}$} \\
\hline & No & $09(6.9)$ & $03(2.3)$ & $03(2.3)$ & $15(11.5)$ & \\
\hline & Neutral & $04(3.1)$ & $07(5.4)$ & 00 & $11(8.5)$ & \\
\hline & Total & $63(48.5)$ & $60(46.2)$ & $07(5.4)$ & $130(100)$ & \\
\hline \multirow{4}{*}{$\begin{array}{l}\text { Women are reluctant to accept } \\
\text { political responsibilities }\end{array}$} & Yes & $54(41.5)$ & $55(42.3)$ & $04(3.1)$ & $113(86.9)$ & \multirow{4}{*}{$\begin{array}{l}(\mathrm{p}=0.001) \\
(\chi 2=18.598)\end{array}$} \\
\hline & No & $06(4.6)$ & $03(2.3)$ & 00 & $09(6.9)$ & \\
\hline & Neutral & $03(2.3)$ & $02(1.5)$ & $03(2.3)$ & $08(6.2)$ & \\
\hline & Total & $63(48.5)$ & $60(46.2)$ & $07(5.4)$ & $130(100)$ & \\
\hline \multirow{4}{*}{$\begin{array}{l}\text { Being a woman it is difficult to } \\
\text { participate in the training programs of } \\
\text { the councillors }\end{array}$} & Yes & $51(39.2)$ & $55(42.3)$ & $03(2.3)$ & $109(83.8)$ & \multirow{4}{*}{$\begin{array}{l}(\mathrm{p}=0.004) \\
(\chi 2=15.601)\end{array}$} \\
\hline & No & $08(6.2)$ & $01(0.8)$ & $03(2.3)$ & $12(9.2)$ & \\
\hline & Neutral & $04(3.1)$ & $04(3.1)$ & $01(0.8)$ & $09(6.9)$ & \\
\hline & Total & $63(48.5)$ & $60(46.2)$ & $07(5.4)$ & $130(100)$ & \\
\hline \multirow{4}{*}{$\begin{array}{l}\text { Women have easily access to decision } \\
\text { making in politics }\end{array}$} & Yes & $02(1.5)$ & $08(6.2)$ & $02(1.5)$ & $12(9.2)$ & \multirow{4}{*}{$\begin{array}{l}(\mathrm{p}=0.029) \\
(\chi 2=10.758)\end{array}$} \\
\hline & No & $56(43.1)$ & $42(32.3)$ & $05(3.8)$ & $103(79.2)$ & \\
\hline & Neutral & $05(3.8)$ & $10(7.7)$ & 00 & $15(11.5)$ & \\
\hline & Total & $63(48.5)$ & $60(46.2)$ & $07(5.4)$ & $130(100)$ & \\
\hline \multirow{4}{*}{$\begin{array}{l}\text { Developmental funds are equally } \\
\text { distributed for male and female } \\
\text { problems / issues at council and } \\
\text { district level }\end{array}$} & Yes & $53(40.8)$ & $48(36.9)$ & $06(4.6)$ & $107(82.3)$ & \multirow{4}{*}{$\begin{array}{l}(\mathrm{p}=0.178) \\
(\chi 2=06.301)\end{array}$} \\
\hline & No & $10(7.7)$ & $07(5.4)$ & $01(0.8)$ & $18(13.8)$ & \\
\hline & Neutral & 00 & $05(3.8)$ & 00 & $05(3.8)$ & \\
\hline & Total & $63(48.5)$ & $60(46.2)$ & $07(5.4)$ & $130(100)$ & \\
\hline \multirow{4}{*}{$\begin{array}{l}\text { Women can supervise developmental } \\
\text { projects efficiently in their areas }\end{array}$} & Yes & $14(10.8)$ & $05(3.8)$ & $02(1.5)$ & $21(16.2)$ & \multirow{4}{*}{$\begin{array}{l}(\mathrm{p}=0.026) \\
(\chi 2=11.074)\end{array}$} \\
\hline & No & $49(37.7)$ & $50(38.5)$ & $04(3.1)$ & $103(79.2)$ & \\
\hline & Neutral & 00 & $05(3.8)$ & $01(0.8)$ & $06(4.6)$ & \\
\hline & Total & $63(48.5)$ & $60(46.2)$ & $07(5.4)$ & $130(100)$ & \\
\hline \multirow{4}{*}{$\begin{array}{l}\text { Pakhtun allow women to cast vote and } \\
\text { participate in politics }\end{array}$} & Yes & $04(3.1)$ & $15(11.5)$ & 00 & $19(14.6)$ & \multirow{4}{*}{$\begin{array}{l}(\mathrm{p}=0.000) \\
(\chi 2=34.135)\end{array}$} \\
\hline & No & $58(44.6)$ & $43(33.1)$ & $04(3.1)$ & $105(80.8)$ & \\
\hline & Neutral & $01(0.8)$ & $02(1.5)$ & $03(2.3)$ & $06(4.6)$ & \\
\hline & Total & $63(48.5)$ & $60(46.2)$ & $07(5.4)$ & $130(100)$ & \\
\hline \multirow{4}{*}{$\begin{array}{l}\text { Patriarchy/Male dominancy is the main } \\
\text { cause of women low participation in } \\
\text { politics }\end{array}$} & Yes & $57(43.8)$ & $53(40.8)$ & $04(3.1)$ & $114(87.7)$ & \multirow{4}{*}{$\begin{array}{l}(\mathrm{p}=0.000) \\
(\chi 2=20.785)\end{array}$} \\
\hline & No & $04(3.1)$ & $05(03.8)$ & 00 & $09(6.9)$ & \\
\hline & Neutral & $02(1.5)$ & $02(1.5)$ & $03(2.3)$ & $07(5.4)$ & \\
\hline & Total & $63(48.5)$ & $60(46.2)$ & $07(5.4)$ & $130(100)$ & \\
\hline \multirow{4}{*}{$\begin{array}{l}\text { Females are considered as low strata } \\
\text { among Pakhtuns }\end{array}$} & Yes & $14(10.8)$ & $15(11.5)$ & $03(2.3)$ & $32(24.6)$ & \multirow{4}{*}{$\begin{array}{l}(\mathrm{p}=0.733) \\
(\chi 2=02.016)\end{array}$} \\
\hline & No & $48(36.9)$ & $43(33.1)$ & $04(3.1)$ & $95(73.1)$ & \\
\hline & Neutral & $01(0.8)$ & $02(1.5)$ & 00 & $03(2.3)$ & \\
\hline & Total & $63(48.5)$ & $60(46.2)$ & $07(5.4)$ & $130(100)$ & \\
\hline \multirow{4}{*}{$\begin{array}{l}\text { Unmarried women performance is } \\
\text { best in politics as compared to a } \\
\text { married woman }\end{array}$} & Yes & $59(45.4)$ & $52(40.0)$ & $01(0.8)$ & $112(86.2)$ & \\
\hline & No & $03(2.3)$ & $02(1.5)$ & $01(0.8)$ & $06(4.6)$ & $(\mathrm{p}=0.000)$ \\
\hline & Neutral & $01(0.8)$ & $06(4.6)$ & $05(3.8)$ & $12(9.2)$ & $\left(\chi^{2}=39.607\right)$ \\
\hline & Total & $63(48.5)$ & $60(46.2)$ & $07(5.4)$ & $130(100)$ & \\
\hline & Yes & $54(41.5)$ & $51(39.2)$ & $02(1.5)$ & $107(82.3)$ & \\
\hline & No & $04(3.1)$ & $04(3.1)$ & $02(1.5)$ & $10(7.7)$ & $(\mathrm{p}=0.005)$ \\
\hline Politics in our country is class-based & Neutral & $05(3.8)$ & $05(3.8)$ & $03(2.3)$ & $13(10.0)$ & $\left(\chi^{2}=14.786\right)$ \\
\hline & Total & $63(48.5)$ & $60(46.2)$ & $07(5.4)$ & $130(100)$ & \\
\hline
\end{tabular}

The figures in the table denote frequency while figures in parenthesis denote percentage. The symbol (P) represents the significance level and $(\chi 2)$ represents the value of chi square. 


\section{Conclusion}

The study titled "Factors affecting women leadership (A case study of District Swat)" was conducted in the selected Tehsils with main objective of assassinating that factor affecting the women leadership. When with capabilities of leadership had proven their with delivering on path of development albeit facing difficulties in communicating at political front. The study also found that male gender had an open recognition to women say declaring then as equal in politics and adjusted them as true manager for executing various development projects with maximum involvement of the troubling factors of patriarchy being a rigid part of Pakhtoon culture. The study also recommended liberty of women to participate in the political arena on social grounds. However, class considerations were immanent. It is suggested that participation should be abilities based rather having any family support from behind.

\section{References}

Alo, P. (2006). The Prothom Alo (Dhaka). Bangla national daily Newspaper, P-16.

Aziz, J. (2020). The Participation of Women in Politics in respect of Religion. A Case Study of Charsadda District of Khyber Pakhtunkhwa, Pakistan, Bannu University Research Journal in Islamic Studies.7(1), 19-26

Cleveland, H. (1985). The knowledge executive. New York: E. P. Dutton.

Clinton, H. (2008). YouTube Video of an excerpted $Q \& A$ time with Hillary Clinton during the 2008 New Hampshire primary with voters. Retrieved from http://www.youtube.com/watch?v=6qgWH89qWks

Coleman, G. (2004). The political agnosticism of free and open source software and the inadvertent politics of contrast. Anthropological Quarterly, 77(3), 507-519.

Eagly, A. H., \& Carli, S. J. (2002). Role congruity theory of prejudice toward female leaders. Psychological Review, 109(3), 573-598.

Eagly, A. H., Makhijani, M. G., \& Klonsky, B. G. (1992). Gender and the evaluation of leaders: A meta-analysis. Psychological bulletin, 111(1), 3.

Goetz, C. G., Poewe, W., Rascol, O., Sampaio, C., Stebbins, G. T., Counsell, C., ... \& Yahr, M. D. (2004). Movement Disorder Society Task Force report on the Hoehn and Yahr staging scale: status and recommendations the Movement Disorder Society Task Force on rating scales for Parkinson's disease. Movement disorders, 19(9), 10201028.

Haque, Z. U., \& Ji, T. (2003). Cheddar whey processing and source: II. Effect on non-fat ice cream and yoghurt 1. International journal of food science \& technology, 38(4), 463473.

Kanter, R. M. (1977). Men and women of the corporation. New York: Basic Books.

Loden, M. 1985. Feminine leadership, or how to succeed in business without being one of the boys. New York: Times Books.

MCcall, P. and Robert, B. (1975). Fundamental statistic for psychology $2^{\text {nd }}$ edition. Harcourt brace Jovanovich, Inc, (New York, USA).

Mukhopadhyay, M. (2016). Mainstreaming gender or "streaming" gender away: feminists marooned in the development business. In The Palgrave Handbook of Gender and Development (pp. 77-91). Palgrave Macmillan, London.

Norris, P. (2013). Women's legislative participation in Western Europe. In Women and Politics in Western (pp. 98-112). Routledge. 
Sekaran, U. (2010). Research Methods for Business: A Skill Building Approach Singapore: John Willey danSonc.

Shamim, I., \& Nasreen, M. (2002). Gender and local governance: A new discourse in development. JOURNAL OF SOCIAL STUDIES-DHAKA-, 50-87.

Valian, V. (1998). Why so slow: The advancement of women. Cambridge, MA: MIT Press. 